\title{
Assessment of effect of ethanolic extract of Tephrosia purpurea (L.) Pers., Fabaceae, activity on lithium-pilocarpine induced Status epilepticus and oxidative stress in Wistar rats
}

\author{
Asuntha G, ,1 Prasannaraju $Y^{2}$ Sujatha D, ${ }^{3}$ Prasad KVSRG ${ }^{3}$
}

\author{
${ }^{1}$ Department of Pharmacy, S P W Polytechnic, Tirupati-517502, India, \\ ${ }^{2}$ Faculty of Pharmaceutical Sciences, UCSI University, \#1, Menara Gading, UCSI Heights, 56000 Kuala Lumpur, \\ Malaysia, \\ ${ }^{3}$ Institute of Pharmaceutical Technology, Sri Padmavati Mahila Visvavidyalayam (A Women's University), Tirupati- \\ 517502, India.
}

\begin{abstract}
RESUMO: “Avaliação do efeito do extrato etanólico da Tephrosia purpurea (L.) Pers., Fabaceae, sobre o status epilepticus induzido por lítio-pilocarpina e estresse oxidativo, em ratos Wistar". Tephrosia purpurea (L.) Pers., Fabaceae, é conhecida pelo seu uso no controle e tratamento de uma variedade de distúrbios epilépticos no sistema indiano de medicina. O presente estudo pretende avaliar de forma sistemática T. purpurea e verificar essa alegação. Status epilepticus foi induzido em ratos albinos machos da linhagem Wistar pela administração de pilocarpina (30 $\mathrm{mg} / \mathrm{kg}$, i.p.) $24 \mathrm{~h}$ após o cloreto de lítio ( $3 \mathrm{mEq} / \mathrm{kg}$, i.p.). Diferentes doses do extrato de T. purpurea foram administrados por via oral uma hora antes da injeção de pilocarpina. A gravidade do status epilepticus foi observada e registrada a cada 15 min até 90 min e, posteriormente, a cada 30 min até 180 min, utilizando um sistema de pontuação. A peroxidação lipídica in vivo do tecido cerebral de ratos foi avaliada. A atividade captadora de radicais livres do extrato da planta foi avaliada in vitro. A interação entre o extrato da planta e 2-difenil-2-picril hidrazil (DPPH) também foi observada in vitro para atividade sequestradora de radicais livres. A gravidade do status epilepticus foi reduzida com a administração do extrato etanólico da T. purpurea. Extrato etanólico da planta apresentou, tanto in vivo quanto in vitro atividade antioxidante. O extrato etanólico da T. purpurea parece ser útil no controle de lítio de status epilepticus induzido pela pilocarpina em ratos albinos da linhagem Wistar.
\end{abstract}

Unitermos: Radical livre, MDA, antioxidante, peroxidação lipídica, atividade antiepileptica flavonois.

\begin{abstract}
Tephrosia purpurea (L.) Pers., Fabaceae, is claimed to be of use in the control and treatment of a variety of epileptic disorders in Indian system of medicine. The present study plans to systematically evaluate $T$. purpurea and to verify this claim. Status epilepticus was induced in male albino rats of Wistar strain by administration of pilocarpine $(30 \mathrm{mg} / \mathrm{kg}$, i.p.) $24 \mathrm{~h}$ after lithium chloride ( $3 \mathrm{mEq} / \mathrm{kg}$, i.p.). Different doses of the extract of $T$. purpurea were administered orally one hour before the injection of pilocarpine. The severity of status epilepticus was observed and recorded every $15 \mathrm{~min}$ till $90 \mathrm{~min}$ and thereafter every $30 \mathrm{~min}$ till $180 \mathrm{~min}$, using the scoring system. The in vivo lipid peroxidation of rat brain tissue was measured. The in vitro NO free radical scavenging activity of plant extract was assessed. The interaction between plant extract and 2-diphenyl-2-picryl hydrazyl (DPPH) was also observed for in vitro free radical scavenging activity. The severity of status epilepticus was reduced with the administration of ethanol extract of $T$. purpurea. Ethanol extract of the plant exhibited both in vivo and in vitro antioxidant activity. The ethanolic extract of T. purpurea was found to be useful to control lithium-pilocarpine induced status epilepticus in albino rats of Wistar strain.
\end{abstract}

Keywords: Free radical scavenging, MDA, antioxidant, lipid peroxidation, antiepileptic activity, flavonols. 


\section{INTRODUCTION}

Convulsive status epilepticus is a neurological emergency associated with high morbidity and mortality. It is defined as a condition in which there is either more than $30 \mathrm{~min}$ of continuous seizure activity, or two or more sequential seizures without recovery of full consciousness between the seizures (Kameshwar et al., 2007). The principal causes of the condition are abrupt antiepileptic drug (AED) withdrawal or inappropriate switches of AED treatment, cerebrovascular disease, febrile illness, central nervous system (CNS) infections, CNS malignancy, metabolic disorders and drug toxicity. The first line of drugs in the management includes benzodiazepines, phenytoin and phenobarbital. The second line drugs include intravenous anesthetics such as barbiturates, ketamine and propofol (Pitt-Miller et al., 1994).

Increased oxidative stress has a role in the pathogenesis of coronary heart disease, neurodegenerative diseases, arthritis, epilepsy, cataract formation and immune system dysregulation. Enzymes and other small molecular antioxidants can protect the experimental animals from the harmful effects of free radicals. The level of oxidative stress is used to identify an animal at risk for the development of the disease, or to monitor therapies directed at the disease (Uday et al., 1990).

Pilocarpine-induced status epilepticus model has provided information on the behavioral and neurochemical characteristics associated with seizure activity. It demonstrated permanent changes in different biochemical systems during status epilepticus. An increase in lipid peroxidation and excessive free radical formation occur during status epilepticus induced by pilocarpine (Erakovie et al., 2000).

According to the World Health Organization, more than one billion people rely on plant and traditional medicines worldwide for the treatment of chronic ailments. During 1950s, there was a major revolution in clinical neuropharmacology and psychopharmacology. Since then effective plant drugs were discovered for CNS disorders such as epilepsy, psychosis, depression and anxiety. The brain is the most complex organ of our body. Only a few drugs are approved by regulatory authorities to treat multi-factorial ailments of the CNS. Natural products have played a significant role in the management of neuropsychiatric disorders.

Convulsive status epilepticus is one of the dysfunctions of the nervous system. Up to $5 \%$ of the world population develops convulsions in their lifetime. Several plants used for the treatment of epilepsy in different systems of traditional medicine, have shown activity when tested employing modern bioassay methods, but many such plants remain to be scientifically investigated. Despite the availability of a large number of antiepileptics, current treatment is far from satisfactory. Approximately $30 \%$ of the patients continue to have seizures with current antiepileptic drug therapy (Holmes, 1993). Thus, there is a continued need to evaluate newer, more effective and safer agents for the treatment of epilepsy.

Tephrosia purpurea (L.) Pers., Fabaceae, is claimed to be an antiepileptic according to the Indian indigenous system of medicine. Systematic pharmacological studies have not been carried out to support this claim (Dhawan, 1995). Hence, this present study was carried out to evaluate T. purpurea's effect on status epilepticus and oxidative stress and to verify this claim. The rationale behind selecting the plant is its extensive use by the practitioners of traditional medicine in the control of epilepsy.

\section{MATERIAL AND METHODS}

Pentylenetetrazole and pilocarpine nitrate were purchased from Sigma-Aldrich, USA. Lithium chloride, HPLC grade chemicals and solvents of analytical grade were purchased from SD Fine Chem, Mumbai, India. Diazepam and other chemicals were obtained from Ranbaxy, New Delhi, India.

\section{Plant collection and extract preparation}

The whole plant of Tephrosia purpurea (L.) Pers., Fabaceae, was collected in the surroundings of Tirupati, Chittoor district, Andhra Pradesh, India in the month of April-May according to its seasonal availability. The plant was identified and authenticated by Prof. T. Vedavathi (Retd.), Department of Botany, Sri Venkateswara Arts and Science College, Tirupati, India. A voucher specimen was deposited at Institute of Pharmaceutical Technology, A Women's University, Tirupati, India (Ref. No.: 03/TP/07-IPT-SPMVV/ TPT/2004).

The collected plant material was shade dried at room temperature in the laboratory. After drying, the plant material was powdered and passed through the sieve (coarse 10/44). About $200 \mathrm{~g}$ of plant powder was extracted with $1000 \mathrm{~mL}$ of $95 \%$ ethanol under reflux by heating over a water bath. The extracts were then vacuum dried. The yield of ethanolic extract of T. purpurea was $31.23 \%(\mathrm{w} / \mathrm{w})$. Suspensions of plant extract were prepared with $2 \%$ Tween 80 , before administration to animals.

\section{Experimental animals}

Male albino rats of Wistar strain weighing 150$200 \mathrm{~g}$ were used for the study. They were housed in polypropylene cages and were maintained under standard laboratory conditions with a natural light-dark cycle and were allowed free access to standard rat pellet diet (Lipton India Ltd.) and drinking water. The animals were 
acclimatized to laboratory conditions for ten days before starting the experiment. The experimental protocol was approved by the institutional animal ethical committee (Ref. No: 1220/a/08/CPCSEA).

\section{Acute toxicity and gross behavioral changes}

Ethanolic extract used in this study was subjected to acute toxicity studies. Healthy adult albino rats were fasted overnight with free access to drinking water. For each plant extract, they were divided into six groups, each containing six animals. Group- 1 animals served as control and received distilled water $(2 \mathrm{~mL} / \mathrm{kg} /$ oral $)$. Group 2 to 6 animals received $0.25,0.5,1.0,2.0$ and $4.0 \mathrm{~g} / \mathrm{kg}$ of ethanolic extract orally by gastric intubation using a soft rubber catheter. The animals were observed continuously for $2 \mathrm{~h}$ and then intermittently at gaps of one hour till $24 \mathrm{~h}$ for behavioral, neurological and autonomic profiles. The animals were observed for mortality at the end of $48^{\text {th }} \mathrm{h}$ to calculate LD50 (Gupta et al., 2002).

\section{Lithium- pilocarpine induced status epilepticus}

Thirty rats were divided randomly into five groups $(n=6)$. Group 1 animals (control) were administered distilled water $(2.0 \mathrm{~mL} / \mathrm{kg}$, oral). Group 2 animals (reference standard) were treated with diazepam (2.0 $\mathrm{mg} / \mathrm{kg}$, i.p.) while Group 3 to 5 animals were administered 250, 500 and $1000 \mathrm{mg} / \mathrm{kg}$ orally of the extract, respectively. Twenty four hours prior to treatment, all the rats received lithium chloride ( $3 \mathrm{mEq} / \mathrm{kg}$, i.p.). One hour after treatment, status epilepticus was induced by administering pilocarpine $(30 \mathrm{mg} / \mathrm{kg}$, i.p.). The severity of status epilepticus was observed and recorded every 15 min until the $90^{\text {th }} \mathrm{min}$ and thereafter every $30 \mathrm{~min}$ until 180th min, using Racine scoring system: 0 (no response); 1 (fictive scratching); 2 (tremors); 3 (head nodding); 4 (forelimb clonus) and 5 (rearing and fall back) (Racine, 1972).

\section{Effect on brain lipid peroxidation}

For ethanolic extract of T. purpurea, the animals were randomly divided into five groups $(n=6)$. Group 1 animals were kept as control and were administered distilled water $(2.0 \mathrm{~mL} / \mathrm{kg}$, oral $)$. Group 2 animals were administered with pentylenetetrazole (PTZ) $(70 \mathrm{mg} / \mathrm{kg})$ subcutaneously as a reference standard. Group 3 to 5 animals were administered 250,500 and $1000 \mathrm{mg} / \mathrm{kg}$ of the ethanolic extract orally. One hour after the administration of plant ethanolic extract, PTZ (70 $\mathrm{mg} / \mathrm{kg})$ was injected subcutaneously to all test group animals. Upon observing of onset of convulsions after the administration of PTZ to Group 2-5 animals, the animals were sacrificed by decapitation including control group. The brains were retrieved from the ice-chamber and submerged in $5 \mathrm{~mL}$ of methanol and homogenized and centrifuged at 10,000 $\mathrm{rpm}$ at $-10{ }^{\circ} \mathrm{C}$ for $15 \mathrm{~min}$ for lipid peroxidation assay. The assay is based on the reaction between malondialdehyde (MDA) and thiobarbituric acid (TBA). The MDA-TBA complex was measured at $532 \mathrm{~nm}$. To a $10 \mathrm{~mL}$ volumetric flask, $0.5 \mathrm{~mL}$ of supernatant of brain homogenate and 2.5 $\mathrm{mL}$ of trochloroacetic acid (TCA) were added and kept aside. After $15 \mathrm{~min}, 1.5 \mathrm{~mL}$ of TCA and $3 \mathrm{~mL}$ of TBA were added to flask and then placed over a water bath for $30 \mathrm{~min}$. The flask contents were shaken for $5 \mathrm{~min}$ and centrifuged at $2000 \mathrm{rpm}$ for $15 \mathrm{~min}$. A clear supernatant was collected from centrifugation (Atilla Ilhan et al., 2005). The optical density of the supernatant was read against a blank in Shimadzu UV3600 spectrophotometer. The lipid peroxidation levels were expressed as micromoles of MDA formed/g of brain tissue.

\section{In-vitro nitric oxide (NO) scavenging activity}

NO generated as a result of decomposition of sodium nitroprusside in an aqueous medium, interacts with oxygen at physiological $\mathrm{pH}$ to produce nitrite ions, which are measured by using Griess reagent. The absorbance of the chromophore formed during the diazotization of nitrite with sulphanilamide and subsequent coupling with $N$-napthylethylenediamine was read at $546 \mathrm{~nm}$ and referred to the absorbance of standard solution of potassium nitrite, treated the same way with Griess reagent. Clear solutions of the extract of $0.1,0.2$, $0.4,0.8$ and $1 \mu \mathrm{g} / \mathrm{mL}$ concentrations were prepared. One $\mathrm{mL}$ of sodium nitroprusside $(10 \mu \mathrm{M} / \mathrm{L})$ in $\mathrm{pH} 7.7$ phosphate buffer was added to each tube containing the plant ethanolic extract. The mixtures were incubated at 25 ${ }^{\circ} \mathrm{C}$ for $2 \mathrm{~h}$. An aliquot of $0.5 \mathrm{~mL}$ of the incubation solution was diluted with $0.5 \mathrm{~mL}$ of Griess reagent. Ascorbic acid was used as a positive control (Green et al., 1982).

\section{Interaction of the plant ethanolic extract with stable free radical 2-diphenyl-2-picryl hydrazyl (DPPH)}

This assay is based on the measurement of the scavenging ability of antioxidant test substances towards the stable radical. The free radical scavenging activity of the ethanolic extract of plant was examined in vitro using DPPH radical. Different concentrations of the extract $(0.1=1 \mu \mathrm{g} / \mathrm{mL})$ were added to $100 \mu \mathrm{g}$ DPPH in ethanol and the tubes were maintained ambient temperature for $20 \mathrm{~min}$ and the absorbance was measured at $517 \mathrm{~nm}$. Ascorbic acid was used as a positive control (Blois, 1958).

\section{Statistical analysis}

The data was expressed as Mean \pm SEM. Statistical analysis was performed by ANOVA test for multiple comparisons followed by Tukey-Kramer test. In addition 
lithium-pilocarpine induced seizures were analyzed using Kruskal-Wallis ANOVA followed by Dunnet's test. The statistical significance was set accordingly.

\section{RESULTS}

\section{Acute toxicity and gross behavioral changes}

The ethanolic extract of $T$. purpurea did not exhibit any gross behavioral changes or manifestations of toxic symptoms such as weight loss, increased or decreased motor activity, tremors, convulsions, muscle spasm, spasticity, loss of right reflex, sedation, arching and rolling, lacrimation, diarrhea, and urination, in the animals, over $24 \mathrm{~h}$. Ethanolic extract of $T$. purpurea (EETP) was found to be nonlethal even at the maximum single dose of $4.0 \mathrm{~g} / \mathrm{kg}$, orally. Hence, doses of the ethanolic extracts selected for the study were 250, 500 and $1000 \mathrm{mg} / \mathrm{kg}$, orally.

\section{Lithium- pilocarpine induced status epilepticus}

All the animals from control group exhibited stage four seizures within $45 \mathrm{~min}$ after pilocarpine injection. Group 2 animals pre-medicated with reference standard drug diazepam, did not demonstrate stage 2 seizures or beyond. The EETP significantly $(p<0.01)$ diminished the lithium-pilocarpine induced status epilepticus in all test groups of animals at 1000 $\mathrm{mg} / \mathrm{kg}$ dose when compared to control group $(p<0.001)$ and none of the animals exhibited stage 4 seizures. The animals were almost normal in behavior after $180 \mathrm{~min}$. The results are shown in Table 1 .

\section{Effect of ethanolic extract of Tephrosia purpurea on brain lipid peroxidation}

Pentylenetetrazole (PTZ) was used induce lipid peroxidation in the brain. From the PTZ treated group 2 animals, malondialdehyde (MDA) content was observed as $1.82 \mu \mathrm{M} / \mathrm{g}$ and compared to the control group value of $0.87 \mu \mathrm{M} / \mathrm{g}$. The EETP has shown a significant $(p<0.001)$ decrease of MDA content in tested group animals as 16.09, 20.69 and 55.17\% at 250,500 and $1000 \mathrm{mg} / \mathrm{kg}$, oral doses respectively when compared to the control group animals. The results are presented in Table 2.

\section{In-vitro antioxidant activity}

The ethanolic extract of Tephrosia purpurea exhibited a significant $(p<0.001)$ concentrationdependent in vitro antioxidant activity against $\mathrm{NO}$ scavenging at all $(0.1-1 \mu \mathrm{g} / \mathrm{mL})$ test concentrations when compared with antioxidant activity of ascorbic acid, a positive control. The ethanolic extract of $T$. purpurea has also demonstrated a significant $(p<0.001)$ in vitro antioxidant activity against stable free radical 2-diphenyl-2-picryl hydrazyl (DPPH) scavenging at all $(0.1-1 \mu \mathrm{g} / \mathrm{mL})$ test concentrations, when compared

Table 1. Effect of ethanolic extract of Tephrosia purpurea (L.) Pers., Fabaceae, (EETP) on lithium-pilocarpine- induced status epilepticus.

\begin{tabular}{cccccc}
\hline $\begin{array}{c}\text { Time after } \\
\text { pilocarpine (min) }\end{array}$ & $\begin{array}{c}\text { Group 1 } \\
\text { Vehicle } \\
(2 \mathrm{ml} / \mathrm{kg} / \text { p.o. })\end{array}$ & $\begin{array}{c}\text { Group 2 } \\
\text { Diazepam } \\
(2 \mathrm{mg} / \mathrm{kg} / \mathrm{i} . \mathrm{p} .)\end{array}$ & $\begin{array}{c}\text { Group 3 } \\
\text { EETP } \\
(250 \mathrm{mg} / \mathrm{kg})\end{array}$ & $\begin{array}{c}\text { Group 4 } \\
\text { EETP } \\
(500 \mathrm{mg} / \mathrm{kg})\end{array}$ & $\begin{array}{c}\text { Group 5 } \\
\text { EETP } \\
(1000 \mathrm{mg} / \mathrm{kg})\end{array}$ \\
\hline 15 & $1.5 \pm 0.20$ & $0.50 \pm 0.45$ & $1.20 \pm 0.32$ & $0.50 \pm 0.10$ & $0.00 \pm 0.10^{*}$ \\
30 & $3.00 \pm 0.49$ & $0.50 \pm 0.82^{* *}$ & $2.50 \pm 0.30$ & $1.50 \pm 0.20$ & $0.00 \pm 0.00^{*}$ \\
45 & $3.80 \pm 0.20$ & $0.70 \pm 0.20^{* *}$ & $3.50 \pm 0.10$ & $1.50 \pm 0.10$ & $1.00 \pm 0.50^{*}$ \\
60 & $4.00 \pm 0.07$ & $1.00 \pm 0.30^{*}$ & $3.30 \pm 0.10$ & $1.80 \pm 0.20$ & $1.30 \pm 0.09^{*}$ \\
75 & $4.50 \pm 0.20$ & $1.00 \pm 0.40^{*}$ & $3.50 \pm 0.20$ & $3.00 \pm 0.20$ & $2.00 \pm 0.10^{*}$ \\
90 & $5.00 \pm 0.88$ & $1.50 \pm 0.22^{* *}$ & $4.10 \pm 0.20$ & $3.50 \pm 0.10$ & $3.00 \pm 0.75$ \\
120 & $3.80 \pm 0.20$ & $1.00 \pm 0.21^{*}$ & $3.80 \pm 0.21$ & $3.00 \pm 0.10$ & $2.00 \pm 0.20$ \\
150 & $2.00 \pm 0.05$ & $0.50 \pm 0.32^{*}$ & $2.00 \pm 0.35$ & $1.50 \pm 0.45$ & $0.50 \pm 0.10^{*}$ \\
180 & $1.00 \pm 0.68$ & $0.20 \pm 0.11^{* *}$ & $1.00 \pm 0.00$ & $0.00 \pm 0.10$ & $0.00 \pm 0.00$ \\
\hline
\end{tabular}

The results were expressed as mean \pm S.E.M. ${ }^{*} p<0.01,{ }^{*} p<0.001$ as compared to control.

Table 2. Effect of ethanolic extract of Tephrosia purpurea (L.) Pers., Fabaceae, (EETP) on brain MDA content.

\begin{tabular}{cccc}
\hline Group & Treatment & Dose $(\mathrm{mg} / \mathrm{kg})$ & $\mathrm{MDA}(\mu \mathrm{M} / \mathrm{g})$ \\
\hline 1 & Control & $2.0 \mathrm{ml}$ & $0.87 \pm 0.62$ \\
2 & PTZ & 70 & $1.82 \pm 0.24$ \\
3 & EETP+PTZ & 250 & $0.73 \pm 0.70^{*}$ \\
4 & EETP+PTZ & 500 & $0.69 \pm 0.54^{*}$ \\
5 & EETP+PTZ & 1000 & $0.39 \pm 0.71^{*}$ \\
\hline
\end{tabular}

The results were expressed as mean \pm S.E.M. ${ }^{*} p<0.001$ as compared to control group. 
Table 3. Effect of ethanolic extract of Tephrosia purpurea (EETP) on in-vitro free radical scavenging activity.

\begin{tabular}{ccccc}
\hline EETP & \multicolumn{2}{c}{ NO levels $(\mu \mathrm{g} / \mathrm{mL})$} & \multicolumn{2}{c}{ DPPH levels $(\mu \mathrm{g} / \mathrm{mL})$} \\
\cline { 2 - 5 } Concentration $(\mu \mathrm{g} / \mathrm{mL})$ & Ascorbic acid & $18.55 \pm 1.07^{*}$ & Ascorbic acid & EETP \\
\hline 0.1 & $3.6 \pm 0.51$ & $21.0 \pm 2.06^{*}$ & $13.50 \pm 1.12$ & $22.15 \pm 2.07^{*}$ \\
0.2 & $12.7 \pm 1.02$ & $24.75 \pm 4.07^{*}$ & $29.51 \pm 3.24$ & $32.50 \pm 5.28^{*}$ \\
0.4 & $30.8 \pm 4.01$ & $31.85 \pm 2.12^{*}$ & $62.15 \pm 5.96$ & $37.60 \pm 4.13^{*}$ \\
0.8 & $61.25 \pm 7.25$ & $42.2 \pm 5.18^{*}$ & $78.12 \pm 8.23$ & $46.30 \pm 6.17^{*}$ \\
1 & $75.1 \pm 9.36$ & $42.2 \pm$ &
\end{tabular}

The results were expressed as mean \pm S.E.M. ${ }^{*} p<0.001$ as compared to ascorbic acid.

to ascorbic acid antioxidant activity. The results are expressed in Table 3 .

\section{DISCUSSION}

Epilepsy is a common chronic neurological disorder, which imposes a burden on health care systems. It is a manifestation of a variety of diseases with variable mortality. Deaths could be due to the causative etiology itself, such as tumors, degenerative conditions or cerebrovascular diseases. Evidence indicates that the imbalance between excitatory and inhibitory neurotransmission in the brain is the main cause for seizure development in both experimental and clinical situations (MacNamara, 1994).

Pilocarpine induced seizures, is one of the most frequently used model for temporal lobe epilepsy. In this model lithium does not have proconvulsant effect in animals (Ormandy et al., 1991). However, animals pretreated with lithium have limbic seizures, following subconvulsant doses of pilocarpine. The combined effect of lithium-pilocarpine results in the accumulation of acetylcholine, inositol monophosphate and reduction in cortical inositol about ten times greater than the effects obtained with either drug alone (Jope et al., 1987). Our study revealed that the ethanolic extract of $T$. purpurea exhibited dose-dependent reduction in the severity of lithium-pilocarpine induced status epilepticus. The lithium-pilocarpine induced status epilepticus correlates with both electrophysiological and neuropathological characteristics of temporal lobe epilepsy (Klitgaard et al., 2002). Hence, active principles from this plant may be useful in temporal lobe epilepsy.

Oxidative stress in the central nervous system has been shown in several rodent models of experimental epilepsy such as the PTZ-induced seizures model. PTZ may also trigger a variety of biochemical processes including the activation of membrane phospholipases, proteases and nucleases. Alteration in the membrane phospholipid metabolism results in liberation of free fatty acids, diacylglycerols, eicosanoids, lipid peroxides and free radicals (Rauca et al., 1999). Ethanolic extract of Tephrosia purpurea exhibited significant free radical scavenging activity against $\mathrm{NO}$ and DPPH and also reduced the levels of brain MDA.

Medicinal herbs with antioxidants are useful in diseases in which free radicals are involved, such as anoxia, ischemia of brain and epileptic neuronal damage, arteriosclerosis, rheumatic disorders and cancer (El-Tahir et al., 1993). T. purpurea was proved to be a potent chemopreventive agent against renal oxidative stress (Khan et al., 2001). The phytochemical investigations have revealed the presence of rotenoids, isoflavones, flavonones, chalcones and flavonols detected by ethanolic extract of $T$. purpurea could be responsible for the antioxidant activity of the plant (Petter et al., 1981; Damre et al., 2003). Several studies on medicinal plants with free radical scavenging and antioxidant activities indicate that these activities are due to the presence of polyphenols and flavonoids ( $\mathrm{Lu}$ \& Foo, 2001). Earlier chemical studies indicated the presence of phenolic compounds and flavonoids (Rao \& Raju, 1979; 1984). Hence, the antioxidant and free radical scavenging activities of the plant may be due to the presence of these compounds.

Status epilepticus and oxidative stress are thought to be closely interrelated. In the present study, lipid peroxidation and nitrite content were increased after status epilepticus. Lipid peroxidation is an index of irreversible neuronal damage of cell membrane phospholipid and has been suggested as a possible mechanism of epileptic activity. A steady-state balance between the production of nitric oxide and metabolites and their destruction by antioxidant systems is present at normal conditions. The results of present study show an increase in nitrite formation after status epilepticus, suggesting that there is a possible increase in concentrations of ROS, which are often involved in neuronal damage. The results show that pilocarpine induces status epilepticus, which can produce alterations in superoxide activity in different areas, thereby causing neuronal damage. Pilocarpine-induced status epilepticus produces several changes in variables related to the generation and elimination of oxygen free radicals in adult rats (Dymond \& Crandall, 1976). In addition, in the normal physiological state, changes in neuronal activity are accompanied by alterations 
in the metabolic rate, which induce modifications in cerebral blood flow. In pathological states, changes in the blood flow may not occur in the same way. There is clinical and experimental evidence of reduced oxygen availability after status epilepticus. Evidence for the role of free radicals in status epilepticus has been found by using enzymatic and nonenzymatic antioxidant treatment for the protection against seizures and for status epilepticus -induced neuronal damage (Freitas et al., 2005).

\section{CONCLUSION}

The results of lithium-pliocarpine induced status epilepticus model demonstrated that the ethanolic extract of Tephrosia purpurea has significant ability in reducing the severity of status epilepticus. Ethanolic extract of Tephrosia purpurea also possessed both in vitro and in vivo antioxidant activity. Further studies are required to explore the responsible compounds for the activity and also to establish the safe dose and mode of action.

\section{REFERENCES}

Atilla Ilhan, Arif Aladag M, Adbulkadir K, Ayhan B, Ahmet G, Ferah A 2005. Erdosteine ameliorates PTZ-induced oxidative stress in mice seizure model. Brain Res Bul 65: 495-499.

Blois MS 1958. Antioxidant determination by the use of a stable free radical. Nature 181: 1199-1200.

Damre AS, Gokhale AB, Phadke KR, Kulkarni MN, Saraf 2003. Studies on the immunomodulatory activity of flavonoidal fraction of Tephrosia purpurea. Department of Pharmacology, Bombay College of Pharmacy, Mumbai, India. p. 23-34.

Dhawan BN 1995. Centrally acting agents from Indian Plants. In: Koslow S H, Murthy RS, Coelho GV (Eds.). Decade of the Brain: India/USA Research in Mental Health and Neurosciences. Rockville: National Institute of Mental Health. p. 197-202.

Dymond AM, Crandall PH 1976. Oxygen availability and blood flow in the temporal lobes during spontaneous epileptic seizures in men. Brain Res 102: 191-196.

El-Tahir KE, Ashour MM, Al-Harbi MM 1993. The cardiovascular actions of volatile oil of the black seeds (Nigella sativa) in guinea-pigs: elucidation of the mechanism(s) of action. Gen Pharmacol 24: 1123-1131.

Erakovie V, Zupan G, Varljen J, Laginja J, Simonie A 2000. Lithium plus pilocarpine induced status epilepticus: biochemical changes. Neurosci Res 36: 157-166.

Freitas RM, Silvania MMV, Francisca CFS, Glauce SBV, Marta MFF 2005. Oxidative stress in the hippocampus after pilocarpine-induced status epilepticus in Wistar rats. FEBS Journal 272: 1307-1312.
Green LC, Wagner DA, Glogowski J 1982. Analysis of nitrate, nitrite and $(15 \mathrm{~N})$ nitrate in biological fluids. Anal Biochem 165: 215-219.

Gupta S, Shukla R, Prabhu KM, Aggrawal S, Rusia U, Murthy PS 2002. Acute and chronic toxicity studies on partially purified hypoglycemic preparation from water extract of bark of Ficus bengalensis. Ind J Clin Biochem 17: 58-63.

Holmes GL 1993. Critical issues in the treatment of epilepsy. Am J Hosp Pharm 50: 85-116.

Jope RS, Simonato M, Lally K 1987. Acetylcholine content in rat brain elevated by status epilepticus induced by lithium and pilocarpine. J Neurochem 49: 944-951.

Kameshwar P, Pudukode RK, Khaldoon Al-Roomi, Reginald S 2007. Anticonvulsant therapy for status epilepticus. Br J Clin Pharmacol 63: 640-647.

Khan N, Sharma S, Alam A, Saleem M, Sultana S 2001. Tephrosia purpurea ameliorate $N$-diethylnitrosamine and potassium bromate-mediated renal oxidative stress and toxicity in Wistar rats. Pharmacol Toxicol 88: 294-299.

Klitgaard H, Matagne A, Vanneste GJ, Margineanu DG 2002. Pilocarpine-induced epileptogenesis in the rat: impact of initial duration of status epilepticus on electrophysiological and neuropathological alterations. Epileptic Res 51: 93-107.

Lu Y, Foo LY 2001. Antioxidant activities of polyphenols from sage (Salvia officinalis). Food Chem 75: 197202.

MacNamara JO 1994. Cellular and molecular basis of epilepsy. J Neurosci 14: 3413-3425.

Ormandy GC, Song L, Jope RS 1991. Analysis of the convulsant potentiating effects of lithium in rats. Exp Neurol 111: 356-361.

Petter A, Ward RS, Rao EV, Raju NR 1981. 8-substituted flavonoids and 3-substituted 7-oxygenated chalcones from Tephrosia purpurea. J Chem Soc 1: 2491-2495.

Pitt-Miller PL, Elcock BJ, Maharaj M 1994. The management of status epilepticus with a continuous propofol infusion. Anesth Analg 78: 1193-1194.

Racine RJ 1972. Modification of seizure activity by electrical stimulation. II. Motor seizure. Electroencephalogr Clin Neurophysiol 32: 281-294.

Rao EV, Raju NR 1979. Ocurrence of (-)-isolonchocarpin in the roots of Tephrosia purpurea. Phytochemistry 18: 1581-1582.

Rao EV, Raju NR 1984. Two flavonoids from Tephrosia purpurea. Phytochemistry 23: 2339-2342.

Rauca C, Zerbe R, Jantze H 1999. Formation of free hydroxyl radicals after PTZ-induced seizure and kindling. Brain Res 847: 347-351.

Uday B, Dipak D, Ranajit BK 1990. Reactive oxygen species: Oxidative damage and pathogenesis. Curr Sci 77: 658-666. 